\title{
THE EFFECTS OF "FULL FAITH AND CREDIT" AND "ERIE" ON STATE REFUSALS TO ENTERTAIN FOREIGN STATUTORY CLAIMS*
}

The Full Faith and Credit Clause of the Constitution ${ }^{1}$ requires all forums to provide maximum enforcement of substantive rights created by a sister state's statute. ${ }^{2}$ At the same time, states may desire to close their courts to claims arising in another state, either to block "imported" litigation interfering with efficient judicial administration in the forum $;^{3}$ or to dismiss actions when they might be more conveniently pursued in another forum; or because the forum's public policy is antagonistic to the nature of the claim. The Supreme Court has recognized that the mandate of Full Faith and Credit is not absolute ${ }^{6}$ and, consequently, has determined the constitutionality

*First Nat. Bank of Chicago v. United Airlines, Inc., 342 U.S. 396 (1952).

1. U.S. Consr. ArT. IV, $\S 1$; implemented by 28 U.S.C. $\$ 1738$ (Supp. 1951).

2. Hughes v. Fetter, 341 U.S. 609, 612 (1951). See, e.g., Order of Travelers v. Wolfe, 331 U.S. 586 (1947) (statute of limitations); John Hancock Mut. Life Ins. Co. v. Yates, 299 U.S. 178 (1936) (statute making false testimony a material misrepresentation). But the forum is not bound by the procedural aspects of the sister state's statute. E.g., Tennessee Coal, Iron \& R.R. Co. v. George, 233 U.S. 354 (1914) (venue) ; Rogers v. American Employers Ins. Co., 61 F. Supp. 142, 143 (W.D. La. 1945) (insurance "direct action" statute).

3. A state may attempt to exclude imported litigation by (1) limiting venuc, sec, e.g., Ohio General Code $\$ 11273$ (Page, 1937); (2) barring specific parties, see, c.g., N. Y. GEN. CORP. LAW $\$ 225$ (suits by non-resident or foreign corporation against foreign corporation) ; So. Car. CoDE $\S 826$ (1942) (same); (3) restricting service of process on foreign corporations, see, e.g., LA. Rev. STAT. $\$ 12: 202(3)$ (1950) (claims arising out of business in the forum) ; (4) removing jurisdiction for specific causes of action, see, c.g., WIs. Stat. $\$ 331.03$ (1949) (foreign wrongful death actions); N. C. GeN. STAT. 45-21.38 (Michie, 1950) (all mortgage deficiency actions). But whatever the means used, there must be no discrimination between plaintiffs on the basis of their state citizenship. Chambers v. Baltimore \& Ohio R.R., 207 U.S. 142 (1907).

4. See cases cited in Barrett, The Doctrine of Forum Non Conveniens, 35 Carm. L. Rev. 380, 389 n.41 (1947). For discussion of formm non conveniens, consult Blair, The Doctrine of Fornm Non Conveniens in Anglo-American Law, 29 CoL. L. Rev. 1 (1929).

5. Union Trust Co. v. Grosman, 245 U.S. 412 (1918) (land contract contrary to forum policy); Bothwell v. Buckbee, Mears Co., 275 U.S. 274 (1927) (assessment on insurance contract contrary to forum policy). And see N. C. GEN. STAT. 45-21.38 (Michic, 1950) (statute abolishing recovery on all mortgage deficiency actions); RESTATEMENT, CONFLICT OF LAwS $\$ 612$ (1934).

6. E.g., Hughes v. Fetter, 341 U.S. 609, 611 (1951). And see Williams v. State of North Carolina, 317 U.S. 287, 294-5 (1942) (mandate is rigid when judgment is pleaded and flexible when statute is pleaded) ; Bradford Elec. Light Co. v. Clapper, 286 U.S. 145, 160 (1932). Occasionally the forum has been permitted to apply its own substantive law in derogation of a sister state's law. E.g., Pacific Employers Ins. Co. v. Industrial Acc. Comm'n, 306 U.S. 493, 501, 502 (1939) (workmen's compensation); Alaska Packers Ass'n v. Industrial Acc. Comm'n, 294 U.S. 532, 546, 547 (1935) (same). 
of a forum's attempts to close its courts to foreign statutory claims by weighing conflicting interests. Originally, the forum's interest in the controversy was balanced against that of the sister state. ${ }^{7}$ Lately, the Court has balanced the interest of the forum, not against the sister state's interest, but rather against the national interest: the "strong unifying principle ... in the Full Faith and Credit Clause."s

The conflict between a state's exclusionary policy and the national interest in maximum enforcement of foreign statutory claims arose recently in First National Bank of Chicago v. United Air Lines, Inc. ${ }^{0}$ Plaintiff's testate, an Illinois resident, was killed when defendant's airliner crashed in Utah. Defendant, a Delaware corporation, was subject to service of process in both Utah and Illinois. Plaintiff sued on the Utah Death Statute in a federal court in Illinois. ${ }^{10}$ An Illinois statute denied access to Illinois courts on foreign wrongful death actions when service on the defendant was possible in the state in which death occurred. ${ }^{11}$ The Seventh Circuit, affirming the district court's dismissal of the suit, held the Illinois statute a permissible limitation under the Full Faith and Credit Clause. ${ }^{12}$ And, apparently on the theory that Erie R.R. v. Tompkins ${ }^{13}$ does not permit a remedy for a diversity litigant in the federal court where this remedy is not available in the state court, the Seventh Circuit held the statute to deprive the federal court of jurisdiction over the claim. ${ }^{14}$

A divided Supreme Court reversed, holding the Illinois statute an abridgement of the Full Faith and Credit Clause. ${ }^{15}$ The Court rested squarely on its

7. Alaska Packers Ass'n v. Industrial Acc. Comm'n, supra note 6 , at 547. The Court's statement in Hughes v. Fetter, sitpra note 6 , at 612 n.10, that this test was used only when a forum attempted to apply its own substantive law, was erroneous. In Broderick v. Rosner, 294 U.S. 629 (1935), the Court had held that a forum could not deny access to its courts with a prohibitive procedural requirement when the sister state had considerable interest in the claim, and the forum none. Id. at 643-4.

S. Hughes v. Fetter, 341 U.S. 609, 612 (1951).

9. 342 U.S. 396 (1952), reversing 190 F.2d 493 (7th Cir. 1951).

10. The facts of the case are set out at First Nat. Bank of Chicago v. United Air Lines, Inc., 190 F.2d 493, 494 (7th Cir. 1951).

11. "[N]o action shall be brought or prosecuted in this state to recover damages for a death occurring outside of this state where a right of action for such death exists under the laws of the place where such death occurred and service of process in such suit may be had upon the defendant in such place" III. REV. STAT. c. 70, \$2 (1951).

12. First Nat. Bank of Chicago v. United Air Lines, Inc., 190 F.2d 493, 496 (7th Cir. 1951).

13. 304 U.S. 64 (1938).

14. The court did not explain the rationale behind Erie's application in Unitcd Air Lines, but held that the federal court had no jurisdiction solely on the authority of its previous rationale in Trust Co. of Chicago v. Pennsylvania R.R, 183 F.2d 640 (7th Cir. 1950). See First Nat. Bank of Chicago v. United Air Lines, Inc, 190 F.2d 493, 494, 496 (7th Cir. 1951).

15. First Nat. Bank of Chicago v. United Air Lines, Inc, 342 U.S. 396 (1952). 
recent Hughes v. Fetter ${ }^{16}$ decision where, in a suit originating in the state court, it had invalidated a Wisconsin statute barring all out-of-state wrongful death claims. ${ }^{17}$ The possibility of a defendant becoming immune to suit as a result of the exclusionary statute, an objectionable feature of the Wisconsin statute, ${ }^{18}$ was eliminated by the Illinois proviso that precluded suit only where service was possible in the state of the tort. Nevertheless the Court deemed this insufficient to distinguish the Wisconsin case. ${ }^{10}$ Consequently, it is clear that United Air Lines rested entirely on the other grounds set forth in Hughes v. Fetter: (1) the forum's entertainment of local wrongful death actions indicated no public policy antagonistic to the nature of the foreign action;20 (2) the statute closed courts to plaintiffs who were local residents, thus preventing suit where the forum had a "close relationship" to the adjudication of the claim. ${ }^{21}$ Having found the statute unconstitutional in United Air Lines, the Supreme Court avoided discussion of the Seventh Circuit's ruling that Erie bound the federal court in Illinois to apply the state's exclusionary law.22

The Fetter and United Air Lines cases may still permit a forum to exclude foreign statutory claims. Apparently, if a state manifests "antagonism" to a particular claim by refusing to permit its courts to enforce local claims of a similar nature, the Supreme Court is willing to uphold the exclusion. ${ }^{23}$ Aside from "antagonism," however, the court gives no positive indication of other state interests that will justify exclusion in the face of the national interest in maximum enforcement. ${ }^{24}$ But the court did indicate what a state may not do regardless of other interests the state attempts to protect. Residents of the forum generally cannot be denied access to the forum's courts; and exclusion cannot create the possibility that a defendant will be immune from suit if plaintiff is barred from the local

16. 341 U.S. 609 (1951).

17. "The reasons supporting our invalidation of Wisconsin's statute apply with equal force to that of Illinois." First Nat. Bank of Chicago v. United Air Lines, Inc., 342 U.S. 396, 398 (1952).

18. Hughes v. Fetter, 341 U.S. 609,613 (1951).

19. First Nat. Bank of Chicago v. United Air Lines, Inc., 342 U.S. 396, 398 (1952). This difference between the two statutes was the basis on which the Seventh Circuit had distinguished the Fetter case. See First Nat. Bank of Chicago v. United Air Lines, Inc., 190 F.2d 493, 494 (7th Cir. 1951).

20. Hughes v. Fetter, 341 U.S. 609,612 (1951).

21. Id. at 613 .

22. First Nat. Bank of Chicago v. United Air Lines, Inc., 342 U.S. 396, 397-8 (1952). For criticism of the majority's approach, see the concurring opinion, id. at 398-9.

23. Hughes v. Fetter, 341 U.S. 609, 612 (1951); and see Stewart v. Baltimore \& Ohio R.R., 168 U.S. 445, 448-9 (1897); Texas \& Pac. Ry. v. Cox, 145 U.S. 593, 605 (1892).

24. The Court has never been clear on the "state interests"; the result is a "lack of guiding standards." Jackson, Full Faith and Credit-The Laweyer's Clause of the Constitution, 45 CoL. L. REv. 1, 16 (1945). 
forum..$^{25}$ Assuming that some state exclusionary policies will survive the Full Faith and Credit test, the Seventh Circuit's interpretation of Eric will force federal courts to dismiss diversity litigants in all cases where state courts would dismiss. ${ }^{26}$ However, decisions elsewhere indicate that federal courts may not be bound by the state law of dismissal for formm non conveniens. ${ }^{27}$

In balancing state and national interest for purposes of Full Faith and Credit, the Court's emphasis on the forum's attitude toward the nature of the claim may be totally irrelevant. In many instances, even if a state is "antagonistic" to a claim, entertainment of a foreign action in its courts in no way affects activities within the state. ${ }^{28}$ Consequently, adherence to the "antagonism" criterion permits denial of maximum enforcement where the forum, in fact, has no interest at stake. ${ }^{20}$ On the other hand, focusing upon the nature of the claim ignores the actual interest which may prompt a forum to close its courts. For example, the main purpose of the Illinois statute was to prevent importation of litigation. ${ }^{30}$ Yet the Court, while professing

25. Hughes v. Fetter, 341 U.S. 609,613 (1951).

26. First Nat. Bank of Chicago v. United Air Lines, Inc, 190 F.2d 493, 496 (7th Cir. 1951); and see note 14 supra.

27. Prior to the passage of $\$ 1404$ (a) of the Judicial Code, authorizing a federal fornm non conveniens doctrine, courts were divided as to whether they must follow state fornm non conzeniens decisions. Compare Weiss v. Routh, 149 F.2d 193 (2d Cir. 1945) (following), with Gilbert v. Gulf Oil Corp., 153 F.2d $8 \& 3$ (2d Cir. 1946) (refusing to follow), revid on other grounds, 330 U.S. 501 (1947). The Supreme Court refused to rule on the question but used state decisions only to corroborate independent decision of a federal court. Koster v. Lumbermen's Mut. Cas. Co., 330 U.S. 518, 529-30 (1947); Gulf Oil Corp. v. Gilbert, supra at 509; Williams v. Green Bay \& W.R.R, 325 U.S. 549, 558-9 (1946). Commentators interpret these decisions and the passage of $\$ 1404$ (a) to imply that federal courts are not bound by state formm non conzenicns decisions. Aloune, Congurentary on the U.S. Judicial Code 201, 331 (1949); Cumment, Fonum Non Conveniens, A New Federal Doctrine, 56 Yale L.J. 1234, 1248-9 (1947); Note, 56 Yale L.J. 1037, 1045 (1947).

28. See, e.g., N. C. Gen. Stat. 45-21.38 (Michie, 1950), which satisfies the "antagonism" criterion but which applies to a claim beyond the interests of the forum. Bullington v. Angel, 220 N. C. 18, 16 S.E.2d 411 (1941). Paradoxically, a forum must enforce a foreign judgment, as distinguished from a statutory cause of action, despite "antagonistic" effects within the forum. See, e.g., Fauntleroy v. Lum, 210 U.S. 230 (1908) (gambling contract); Sherrer v. Sherrer, 334 U.S. 343 (1948) (divoree). See sources cited note 29 infra.

29. For criticism of the "antagonism" test, see Goodrich, Forcigrs Facts and Local Fancies, 25 VA. L. REv. 26, 30 (1938); Beach, Uniform Interslate Enforecrient of Vestcd Rights, 27 Yale L.J. 656, 6645 (1918); Restatesient, Confzict of LAws $\$ 612$, comment $c$. (1934).

30. First Nat. Bank of Chicago v. United Air Lines, Ine, 190 F.2d 493,495 (7th Cir. 1951). There are no records that reveal legislative intent in passing the statute, sce Communication to Yale Law Journal from George A. Nichols, Legislative Reference Bureau of Illinois, dated April 16,1952, on file in Yale Law Library. But the crowded Illinois 
to balance the national interest against that of the state, never alluded to Illinois' objective in passing the statute.

But while the Court did not weigh the actual interest that Illinois sought to protect, it nevertheless reached a desirable result in declaring the statute unconstitutional. By adopting a balancing test for Full Faith and Credit, the Court has reserved judgment as to the types of interests it will permit a state to protect. At the same time, since a state, to obtain its objectives, may use various methods which impair maximum enforcement to a greater or lesser degree, the Court also becomes the arbiter of permissible means to the approved objective. ${ }^{31}$ Thus, even assuming that the objectives sought by Illinois merited the Court's approval, there is sound basis for the unconstitutionality of the statute in the unreasonableness of its scope. If the statute attempted to bar imported litigation, blanket exclusion of foreign causes of action brought by plaintiffs who reside in Illinois creates an unnecessary impairment of maximum enforcement since these claims are hardly "imported." 32 And if the statute attempted to codify a formm non convonions doctrine based on the assumptions that the state of the tort is the most appropriate site for litigation ${ }^{33}$ and that discretionary dismissal for inconvenient forums creates too much uncertainty, ${ }^{34}$ the blanket exclusion of residents ignored the frequent situations in which the home forum is the most convenient place to sue.

The Supreme Court should recognize discretionary fortm non convenichs and appropriate statutes aimed at blocking imported litigation as exceptions to the Full Faith and Credit mandate. States may suffer from a steady influx of non-resident plaintiffs who bring foreign claims to metropolitan areas ${ }^{\text {at }}$

dockets, see note 37 infra, plus a recent attempt to extend exclusion to all foreign personal injury actions, see Sen. Bill 136, 67th I.11. Gen. Assembly, 1951, clearly corroborate the Seventh Circuit's view.

31. Hughes v. Fetter, 341 U.S. 609,611 (1951). This position of judicial supremacy was severely criticized in the dissent, id. at 620 .

32. Imported litigation refers to the situation where the plaintiff sues "in remote jurisdictions rather than in the district where the accident took place or the plaintiff live[s]." H.R. Rep. No. 613, 80th Cong., 1st Sess. 3 (1947). For discussion sce Dainow, The Inappropriate Forum, 29 IL.. L. Rev. 867 (1935), and sources cited note 4 supra.

33. For discussion see Joiner, Let's Have Michigan Torts Decided in Michigan Courts, 31 Mrсн. ST. B.J. 5,12 (1952); Holt, Statutory Recognition of Fortm Non Conveniens, 29 INs. COUNSEL J. 16, 22 (1952); Jackson, supra note 24, at 23.

34. Although discretionary forum non conveniens may be preferable, it has been criticized for uncertainty, multiplying lawsuits, loss of time, expense, and inefficiency. See Gulf Oil Corp. v. Gilbert, 330 U.S. 501, 516 (1947) (dissenting opinion). But sce Dainow, supra note 32, at 889-90.

35. E.g., experience with FELA tort claims "establishes that the employees of $\mathbf{5 1}$ railroads, during the 5-year period, July 1941 through June 1946, filed a total of 2,512 suits, in remote jurisdictions. . . . More than 92 per cent of all these imported suits were filed in five States: Illinois, California, New York, Minnesota and Missouri." H.R. Rep. No. 613 , supra note 32 . In Illinois during that period, 695 suits were filed in which the 
in search of higher jury verdicts. ${ }^{30}$ The resulting crowded dockets in these areas mean prolonged delay for residents litigating in the forum ${ }^{37}$ and increased tax burdens which the local community must bear to maintain its courts. ${ }^{38}$ The ill effects of imported litigation can be at least mitigated by statutes that will permit resident plaintiffs to sue on a foreign claim and will prevent a defendant's immunity to suit. ${ }^{39}$ Since such enactments would avoid the Supreme Court's objections to the Wisconsin and Illinois statutes, the interests of efficient state judicial administration warrant their survival. Similarly, a discretionary formm non conzenicns doctrine should survive. The doctrine permits courts: (1) to alleviate extreme hardship upon the defendant due to an unfortunate locus of suit and (2) to avoid inept adjudi-

tort and the plaintiff's residence were in a sister state. Hearings before Comsailtec os the Judiciary on H.R. 1639, 80th Cong., 1st Sess. 31 (1947). Sixty-two per cent of the FELA actions pending in Cook County (Chicago and vicinity) were imported from another state. $I d$. at 8 .

36. Hearings, supra note 35, at 5, 101-102; Blair, supra note 4, at 33; Gulf Oil Corp. v. Gilbert, 330 U.S. 501, 510 (1947). "It has been our experience that juries in urban areas are 'sympathetic' and bring in higher jury verdicts. This is particularly true in Chicago. Such reasons do stimulate the 'importation' of foreign causes of action." Communication to the YAlE LAW JouRNal from John MI. O'Connor, Jr., attorney for United Air Lines, dated April 18, 1952, on file in Yale Law Library. The desire to have "urban jurors" will also cause the plaintiff to choose a state rather than a federal court, breause federal panels, encompassing a larger area, may include "rural jurors." Testimony of Floyd E. Thompson, former Chief Justice, Illinois Supreme Court, Hearings, supra note 35, at 19-20. In California, for example, nine out of twelve FELA suits were brought in state courts. Hearings, supra note 35 , at 85 .

37. In 1948-9, 7,343 law jury and non-jury cases were filed in the Superior Court of Cook County (Chicago and vicinity). During that period 6,590 were disposed of, but the backlog of cases still left $\$, 760$ pending. Report of CASEs Disposed of n CoOE Courity, In. FROA SEPT. 6, 1949 to MARCH 31, 1950, on file in Yale Law Library. There is nearly a two year backlog of cases in the Chicago area despite the assistance of downstate judges called in to share the burden. Chicago Tribune, Mray 29, 1950, p. 1, col. 1. See Hearivgs, supra note 35, at 27. See also Collard v. Beach, 93 App. Div. 339, 340-1, 87 N.Y. Supp.

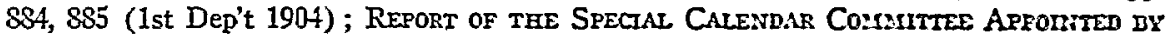
the Appillate Division of tHe Supreare Court, First Dep't 11, 12 (N.Y. 1927).

38. For discussion see Loftus v. Pennsylvania R.R., 107 Ohio St. 352, 369,140 N.E. 94, 99 (1923) ; Barrett, supra note 4, at 414; Blair, supra note 4, at 34; Hansell, The Proper Forun For Suits Against Foreign Corporations, 27 CoL I. Rev. 12, 14 (1927).

39. See, e.g., N. Y. GEN. Corp. LAw \$225 which bars many out-of-state claims brought by a non-resident or a foreign corporation against a foreign corporation. In addition, cl. (4) states that suit is permissible, subject to discretionary forum ron conveniens, if the defendant is doing business within the forum. E.g., Murnan v. Wabash Ry., 246 N.Y. 244, 158 N.E. $50 S$ (1927). The statute as it existed prior to the addition of cl. (4), N.Y. CODE of CIv. Proc. $\$ 1780$ (1910), would also be constitutional since a defendant could always be sued in the state of incorporation. An alternative statute, broader in its application than the New York statute and without a discretionary forsm non conceniens loophole, could constitutionally bar court access to non-residents on all foreign tort claims against a defendant subject to service of process in the state of the tort. See Ill. Sen. Bill 136, supra note 30. 
cation of a claim when only another forum can command access to sources of proof. ${ }^{40}$ While it is true that a resident of the forum may be dismissed under the doctrine, ${ }^{41}$ the individual treatment accorded each case ensures that dismissals will occur only when the "convenience of the parties" and the "ends of justice" so demand. ${ }^{42}$

Wherever states are permitted to exclude foreign statutory claims, federal courts generally should not dismiss diversity litigants under Erie. The Seventh Circuit construes Erie to deprive federal courts of jurisdiction whenever state courts would dismiss an action. ${ }^{43}$ The basis of Eric, however, is the conception that the outcome of a controversy for a diversity litigant in a federal court shall not differ from that of a litigant in the state court. ${ }^{44}$ The only way in which a denial of court access can affect the outcome of a controversy is if the defendant is immune to stit in all other forums. ${ }^{45}$ After Fetter and United Air Lines, immunity cannot constitutionally exist under statutes directed against imported litigation. Nor can it be present in a dismissal under formm non conveniens, for this doctrine pre-

40. See sources cited note 4 supra.

41. E.g., Koster v. Lumbermen's Mut. Cas. Co., 330 U.S. 518 (1947).

42. Id. at 527; Gulf Oil Corp. v. Gilbert, 330 U.S. 501, 507-8 (1947).

43. First Nat. Bank of Chicago v. United Air Lines, Inc., 190 F.2d 493, 494, 496 (7th Cir. 1951). Although 28 U.S.C. $\$ 1652$ (1946) (Rules of Decision Act) made other state statutes binding on federal courts before Erie, exclusionary statutes were not considered controlling. E.g., David Lupton's Sons Co. v. Automobile Club of America, 225 U.S. 489 (1912). After Erie these statutes were considered procedural and consequently still did not control federal courts. E.g., McLean v. York Oil Field Supply Co., 138 F.2d 804 (5th Cir. 1943) ; Stephenson v. Grand Trunk W. Ry., 110 F.2d 401 (7th Cir. 1940). Angel v. Bullington, 330 U.S. 183 (1947), reversed the previous trend by holding a state exclusionary state "substantive" for purposes of Erie. After misinterpretation of Angcl, sce, e.g., Davidson v. Gardner, 172 F.2d 188 (7th Cir. 1949) ; Parker, Erie v. Tompkins in Retrospect: An Analysis Of Its Proper Area and Limits, 35 A.B.A.J. 19, 84 (1949); its holding was finally clarified in Woods v. Interstate Realty Co., 337 U.S. 535, 537 (1949). Subsequently, but prior to United Air Lines, the Seventh Circuit held that the Illinois statute prevented federal courts in Illinois from hearing an action, but not from transferring since federal jurisdiction was not impaired. Trust $C_{0}$. of Chicago v. Penusylvania R.R., 183 F.2d 640, 644, 646 (7th Cir. 1950).

44. Guaranty Trust Co. of New York v. York, 326 U.S. 99, 109 (1945). Otherwise, there would be discrimination against local citizens. Erie R.R. v. Tompkins, 304 U.S. 64, 76 (1938); Woods v. Interstate Realty Co., supra note 43, at 538; Angel v. Bullington, supra note 43, at 192. See Shulman, The Demise of Swift v. Tyson, 47 YALE L.J. 1336, 1347 (1938); Merrigan, Erie to York to Ragen, A Triple Play on the Federal Rulcs, 3 VAND. L. REv. 711, 713 (1950).

45. Thus, in the only Supreme Court decisions on Erie and denial of court access, Angel v. Bullington, 330 U.S. 183 (1947), and Woods v. Interstate Realty Co., 337 U.S. 535 (1949), the forum statutes allowed for possible defendant immunity. In Angcl, the defendant, a North Carolina resident, needed only to stay in his home state to escrape the Virginia cause of action. In Woods, a Mississippi defendant would have been secure in his home state on the local claim brought by the unlicensed foreign corporation. 
supposes the existence of another forum. ${ }^{20}$ Thus, Eric should require that federal courts follow state law only where the forum's dismissal is founded on antagonism to the nature of the claim, without reference to a defendant's possible immunity. Moreover, rejecting Eric in all but "antagonism" cases seems justified practically as well as doctrinally. State exclusionary policies aim at efficient administration of state, not federal, courts. And a dismissal based on state law directly conflicts with the policy of Section 1404(a) of the Judicial Code, which authorizes federal courts to transfer actions to more appropriate forums rather than dismiss. ${ }^{47}$

46. Gulf Oil Corp. v. Gilbert, 330 U.S. 501, 506-7 (1947). See sources cited in note 4 sitpra.

47. Headrick v. Atchison, T. \& S.F. Ry., 182 F.2d 305 (10th Cir. 1950) ; Mrcons, Codiarentary on the U.S. Judictal Code 209 (1949). 